\title{
Nepali Satyagraha: Spring 1947 and Pandit Nehru
}

\section{Introduction}

Prof. Dr. Prem Uprety*

The Satyagraha is a technique of political action, which tries to bring about changes within a conflict situation. In fact it includes the adherence to the stated truth by non-violent behavior, which includes self-suffering. The whole thrust of Satyagraha is to bring about changes by converting the heart the evil doer to morality, reason and justice. It was Mahatma Gandhi, who more or less successfully converted the hearts of the English both in South Africa and India by using this political technique. As the Government of Nepal closed all roads to negotiations the oppositional forces in Nepal took a sharp revolutionary turn in the direction of the Satyagraha movement for the attainment of civil liberties. The fulfilment of the demands of the workers in factories was pushed to the periphery and a movement to root out the arbitrary centralized political culture of Nepal was on its making. ${ }^{1}$

\section{The Satyagraha Movement}

The operation of the Satyagraha was carefully selected at five different points: Biratnagar, Ilam. Birganj, Janakpur and Kathmandu. The help rendered by the Indian Socialist leader, Ram Manohar Lohia, was extremely valuable not only in its planning phase but also its its implementation; and also in equipping the Satyagraha with the new moral courage and the tools of injuctions. The tools of the injunctions laid for the Satyagraha were: non-violence, no molestation of the "blacklegs", no dependence upon alms, but self-support through the help of the working class and no surrender, however, long the strike might be .

The Satyagraha, which lasted from April to September 1947, received an unprecedented success all over the country. Perhaps the Satyagraha was most visible in action in the capital city of Kathmandu itself. The Satyagrahis consisting mainly of the boys and girls led a procession of 30,000 in number in the down town Kathmandu itself. This show of an unique strength had the desired effect. So, the unofficial and the official organizations like the Electricity Department, the Department of Mint, the Nepal Bank and Bir Hospital also went on strike like the Biratnagar mill workers for better pay and

\footnotetext{
Dr. Prem Uprety is Professor of History, Tribhuvan University, Kirtipur, Kathmandu, Nepal.

1. More on Satyagraha as a technique of political action see; Joan Bondurant, Conquest of Violence: the Gandhian Philosophy of Conflict, Berkeley: Unversity of California, 1969, pp. 38-40.
} 
amenities. ${ }^{2}$ It is to be remembered that on the fourth of March 1947, 10,000 workers of the Biratnagar Cotton and Jute Mills went on strike to raise their salaries and other facilities. ${ }^{3}$ The Hindu, a daily newspaper from Madras reported :

The roads and streets of Kathmandu are deserted and the people have become panicy. The normal civic life has been paralyzed... and the liberal minded premier is contemplating resignation. ${ }^{4}$

The government retaliated by mass arrests including the arrests of leaders like Man Mohan Adhikari and B.P. Koirala. Both were taken under heavy escort to Kathmandu, and the journey took a month. As arrests continued, thousands of innocent men and women found themselves breathing in a foul atmosphere in prisons. ${ }^{5}$ The government was also quick to pass the prohibitory order against mass-meetings, and processions in Kathmandu; but it spread like wild fire to the twin cities of Patan and Bhaktapur. In Kathmandu the fiery youths like Puspa Lal, Tanka Bilas, Amir Bahadur and girls defied the prohibitory orders and shouted anti Rana slogans; but some of the slogans were pro-Padam so no the rightist faction among the Ranas got an opportunity to speculate on the Premier's involvement in the campaign. But this was only wishful thinking. The Istihar that was printed in the Gorkhapatra of Baishak 24, 2004 (May 1947) makes the position of the Premier amply clear. it is he who accused the Satyagrahis as being :

A handful of law breakers, who by imitating the tactics of the political parties of other countries has indulged in making derogatory speeches from different political platforms and had incited the people to act against the king, country and the system. ${ }^{6}$

\section{Role of India}

India played a mixed role in the movement. The British government of India, which was about to quit in about three months, though it provided the base in

2. The Hindu, September 29, 1947, p. 6: also Chandra Bikram Budhathoki, "History of Democratic Movement in Nepal" 1931-51 (Ph.D. thesis, Patna University, 1974), pp. 158-61; For a sketch of the Movement see Yuga Bani, April 1, 1948, No. 10, Year I, p. 26.

3. Devendra Raj Upadhyaya, Secretary, Nepal National Congress, "India Must Rush to Resque the Freedom Fighters Before It Is Too Late", News Magazine, February 19, 1949, p 7.

4. $\quad$ The Hindu (Madras), September 29, 1947, p.6.

5. See the Statement by D.B. Pariyar, Secretary, Calcutta Branch of Nepal National Congress, The Hindu, September 29, 1947, p.6.

6. D.R. Regmi, A Century of Family Autocracy in Nepal, Barnaras: Nepal National Congress, 1950, P. 195; Gorkhapatra, B. S. 2004 Baisakh 29 (May 1947), p. 1. 
India for the operation of the Nepal's Satyagraha movement, yet, at times did not hesitate to supress the movement in India. To be illustrative. Birganj was one of the centers of movement. The Satyagrahais like Juddha Prasad Mishra and Gopal Prasad Bhattrai were arrested for taking a procession in Birganj and distributing anti-Rana pamphlets. The Governor (Bada Hakim), thus, imposed a round the clock curfew in the city of Birganj and armed troops were seen marching in trucks. The border of Birganj with Raxaul of India was also patrolled with the state army. So all those who entered Nepal from India were thoroughly searched, and the provincial government of Bihar in co-operation with the Rana government promulgated the section 144 of the Indian Penal Code which banned all meetings and processions in sympathy with Nepal National Congress ${ }^{7}$.

Now Pandit Nehru, who was to be the Prime Minister of free India in about three months, was worried about the duration and the magnitude of the movement and wanted the National Congress and the Rana government to come to a compromise. Nehru, thus, asked the president of the National Congress to suspend the movement and wait for reforms that would be forthcoming. The congress leaders of Nepal were shocked by the new line of approach taken by the Indian leader. Thus, two members of the Nepali National Congress M.P. Koirala and K.B. Pradhan, were sent by the party to Delhi. The meeting between the Nepali delegation and Panditjee took place at 3 p.m. on May 5, 1947. The Nepali team asked Nehru why he had asked the Nepali Satyagrahis to call off the movement ? The reply of Nehru in part ran

The Nepal government has extended her hand of friendship towards us. You know that other nations are also eager to exploit her to their benefit but India must not give this chance. She must take it. This is what I want, and for this I have suggested to stop the movement for the present. ${ }^{8}$

The other nation which Nehru had in mind was no other than the United States. As Britain was about to leave India the United States decided to fill the vacuum by trying to gain a foothold in Nepal. So, in April 1947, President Truman sent Joseph C. Satterwhite as his personal envoy to Nepal. What happened to be the first American official visiting the country. Commenting on the extraordinary mission the New York weekly magazine Time wrote;

7. The Hindu, June 4, 1947, p.4.

8. I am very much grateful to Shri Devendra Raj Upadhyaya for permitting to publish the full text of the interview between the Nepali delegation and Pandit Nehru May 5, 1947. See Appendix 1. 
With Britian's departure from India, Nepal's next door neighbor, has already begun to create a political vacuum into which the US is stepping. ${ }^{9}$

By April 30 an agreement on culture and trade was signed between Nepal and the United States. The U.S. Secretary of State for Foreign Affairs on April 30 made this statement : "the Agreement with Nepal would be the basis for America's interest with India as a whole". ${ }^{10}$ The Soviet commentator M. Dyakov comenting on the new trade and cultural relations between Nepal and the United States observed that "this diplomatic act points to the desire of the American capitalists to make Nepal their colony." ${ }^{11}$ To add to this confusion the Indian press reported that "They (Ranas) also promised to lease to U.S. the eastern part of Nepal, which is rich in minerals." 12

The American interest in Nepal stemed from the cold war politics that dominated the world since the World War II. To deal with the new world order President Truman of the United States came up with the Truman Doctrine, in March 1947. In harmony with the Truman Doctrine, the new U.S. leader, Harry S. Truman, spelled out the four cardinal features of American foreign policy during his inaugural address in 1949. The four features which opened up a wide new horizon for at least two decades is as follows.

a. Unflatering support of the United Nations.

b. The recovery of the war-torn, devastated Europe through the Marshall.

c. Military assistance to the freedom loving countries against aggression.

d. Making available "our scientific advances and industrial progress for the improvement and growth" for the underdeveloped parts of the world. ${ }^{13}$

Thus, according to the clause $\mathrm{c}$ and $\mathrm{d}$ of the American foreign policy Nepal fell under the category of the frontier state as it bordered the Communist China. So United States was determined to check the expansion of communism south of the Himalayas and aid flowed freely into Nepal Himalaya.

9. Time, April 5, 1947, p.10.

10. Statement of American Secretary of State for foreign Affairs April 30, 1947 The Nation, May 1, 1947, p.1.

11. Kashmir Times, May 3, 1947, P.1.

12. Devendra Raj Upadhyaya : "Nepal: Where Nehru's Foreign Policy Failed", The Nation, December 14, 1949, pp. 8-9.

13. For the inaugural speech and the Four Points Program see; Margaret Truman, Harry S. Truman, New York: Pocket Books, 1947, pp. 437-442. 
It is under this background Pandit Jawaharal Nehru extended his friendly hands to the Ranas compelling the Nepali Congress even to call off the Satyagraha movement, which had reached its peak and moving from success to success.

\section{Conclusion}

Thus, form 1947 onwards, India's foreign policy on Nepal was guided by the twin objectives to check both the Chinese and the American influence in Nepal as far as possible. So, this is the reason why the future Prime Minister Nehru compelled the Nepali revolutionaries to call off the Satyagraha movement of the Spring 1947 and the armed revolution against the Ranas of 1950-51 when both were nearing to their completion. So, the Nepali leaders had to compromise their national interest for the so-called India's security and the vision of Nehru, which was suffering from acute Sino-American phobia. It is very unfortunate that the foreign policy makers of the present day India are still deeply sunk in this kind of deep fear syndrome. 
6 Voice of History, Vol. XVI, No. 2 (Dec. 2001)

Appendix - 1 
P. Uprety /Nepali Satyagraha... 7 
8 Voice of History, Vol. XVI, No. 2 (Dec. 2001) 